\title{
PRINSIP-PRINSIP DASAR MANAJEMEN PENDIDIKAN ISLAM DALAM AL-QURAN
}

\author{
Hisam Ahyani \\ STAI Miftahul Huda Al Azhar Banjar \\ hisamahyani@gmail.com
}

\section{Agus Yosep Abduloh}

STAI Miftahul Ulum Tasikmalaya

agusyosepabd01@gmail.com

\section{Tobroni}

SMKN 1 Jatibarang Kabupaten Indramayu

kangmasasobroni@gmail.com

\begin{abstract}
ABSTRAK
Prinsip dasar Manajemen Pendidikan Islam mengandung berbagai prinsip umum yang fleksibel sehingga ia sejalan dengan kemajuan dan perkembangan yang baik. Prinsip-prinsip inilah yang membedakan antara manajemen pendidikan secara umum dengan manjemen pendidikan Islam. Mengenai prinsip-prinsip manajemen pendidikan Islam banyak pakar pendidikan Islam yang berbeda pendapat. Maka dari itu di era yang serba digital ini yaitu Era Revolusi Industri 4.0 perlu adanya revitaslisasi kajian mengenai prinsip-prinsip dalam manajemen pendidikan Islam guna mewujudkan manajemen yang kokoh dan unggul. Jenis penelitian ini adalah penelitian kualitatif dalam penelitian kepustakaan (library research). Adapun pendekatannya menggunakan pendekatannya kulalitatif. Penulis mengambil ayat-ayat yang berkaitan, antara lain yaitu Surat Al-A'raf ayat 29, Surat Al-Ahzab ayat 24, Surat Al-Zumr ayat 33, Surat At-Taubah ayat 119, Surat Muhammad ayat 21, Surat An-Nisa ayat 58, Al-Maidah ayat 8. Hasil temuan dalam penelitian ini adalah bahwa prinsip-prinsip dasar dalam manajemen pendidikan Islam dan relevansinya dalam kehidupan Era Revlusi Industri 4.0 diantaranya meliputi prinsip ikhlas, jujur, amanah dan adil.
\end{abstract}

Kata kunci: prinsip dasar manajemen, Al-Quran, era revolusi Industri 4.0

\section{ABSTRACT}

The basic principles of Islamic Education Management contain various general principles that are flexible so that are in line with good progress and development. These principles distinguish between education management in general and management of Islamic education. Regarding the management principles of Islamic education, many Islamic education experts have different opinions. Therefore, in this all-digital era, namely the era of the Industrial Revolution 4.0, it is necessary to revitalize the study of the principles of Islamic education 
management in order to create strong and superior management. This type of research is qualitative research in library research. The approach used a qualitative approach. The author takes the verses that are related to, among others, Surah Al-A'raf verse 29, Al-Ahzab verse 24, Al-Zumr verse 33, At-Taubah verse 119 , Muhammad verse 21 , An-Nisa verse 58 , and Al-Maidah verse 8 . The findings in this study are that the basic principles in the management of Islamic education and their relevance in the life of the Industrial Revlusion Era 4.0 include the principles sincerity, honesty, trustworthiness and fairness.

Key words: basic principles of management, Al-Quran, industrial revolution era

\section{PENDAHULUAN}

Kata manajemen sendiri berasal dari Bahasa Latin, dengan asal katanya manus yang berarti tangan dan agree yang berarti melakukan. Kata tersebut jika digabungkan maka akan menjadi kata manager yang artinya menangani. Sedangkan dalam Bahasa Arab manajemen diartikan sebagai idaarah, yang asal katanya adaara, yaitu mengatur (Munawwir, 1997, p. 385). Namun dalam Bahasa Inggris kata menejemen berasal dari management dari akar kata to manage yang berarti mengurus, mengatur, melaksanakan, mengelola, dan memperlakukan (Echols \& Hassan, 2006, p. 359). Dari asal kata tersebut diatas muncul kata benda yaitu managemen, dan manager untuk orang yang melakukan kegiatan manajemen. Akhirnya management diterjemahkan ke dalam Bahasa Indonesia menjadi manajemen atau pengelolaan. Adapun manajemen sendiri, dalam Kamus Bahasa Indonesia dimaknai dengan proses pemakaian sumber daya secara efektif untuk mencapai sasaran yang telah ditentukan atau suatu penggunaan sumber daya secara efektif guna mencapai suatu sasaran (Departemen Pendidikan Nasional, 2013, p. 870).

Sedangkan pengertian manajemen dalam Al-Quran terdapat dalam Surat As-Sajdah Ayat 5 sebagai berikut:

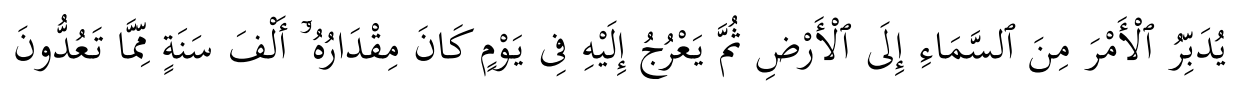

Artinya: Dia mengatur urusan dari langit ke bumi, kemudian (urusan) itu naik kepada-Nya dalam satu hari yang kadarnya adalah seribu tahun menurut perhitunganmu.

Kandungan ayat di atas berisi tentang manajemen dan dapatlah pula diketahui bahwa Allah SWT adalah pengatur alam Al-Mudabbir/manajer. Terkait hal tersebut dapat dihubungkan dengan adanya keteraturan alam raya ini yang merupakan salah satu bukti kebesaran Allah SWT dalam pengelolaan alam ini. Namun dikarenakan manusia yang diciptakan Allah SWT telah dijadikan dengan tujuannya tidak lain dan tidak bukan agar menjadi seorang khalifah/pemimpin di muka bumi ini, maka dia harus mengatur dan mengelola bumi dengan sebaik mungkin sebagaimana Allah SWT mengatur alam jagat raya ini.

Istilah manajemen sebenarnya mengacu kepada proses pelaksanaan aktifiitas yang diselesaikan secara efisien dengan dan melalui pendayagunaan orang lain. Terry (Ilmuan Barat) memberikan defenisi management is a distinct process consisting of planning, organizing, actuating and controlling, performed 
to determine and accomplish stated objectives by the use of human beings and other resources, yaitu manajemen dijadikan suatu proses yang jelas dan terdiri dari suatu tindakan-tindakan perencanaan, pengorganisasian, pelaksanaan, dan pengendalian yang dilaksanakan untuk menentukan serta melaksanakan sasaran dan tujuan yang telah ditentukan dengan menggunakan sumber daya dan sumber- sumber lainnya (Engkoswara \& Komariah, 2012, p. 87).

Prinsip dasar Manajemen Pendidikan Islam mengandung berbagai prinsip umum yang fleksibel sehingga ia sejalan dengan kemajuan dan perkembangan yang baik. Prinsip-prinsip inilah yang membedakan antara manajemen pendidikan secara umum dengan manjemen pendidikan Islam. Mengenai prinsip-prinsip Manajemen Pendidikan Islam banyak pakar pendidikan Islam yang berbeda pendapat, diantaranya Ramayulis berpendapat bahwa prinsip manajemen pendidikan Islam ada delapan yaitu ikhlas, jujur, amanah, adil, tanggung jawab, dinamis, praktis, dan fleksibel (Ramayulis, 2008, p. 262). Sedangkan Langgulung berpendapat bahwa prinsip Manajemen Pendidikan Islam ada tujuh, yaitu iman dan akhlak, keadilan dan persamaan, musyawarah, pembagian kerja dan tugas, berpegang pada fungsi manajemen, pergaulan dan keikhlasan (Langgulung, 2000, p. 248). Dengan mengacu pada salah satu pendapat di atas, maka secara terperinci beberapa diantara prinsip dasar Manajemen Pendidikan Islam dalam Al-Quran perlu adanya pembahasan yang mendalam guna menjadikan keberfungsian prinsip-prinsip dasar Manajemen Pendidikan Islam dan penerapannya dalam sekolah maupun madrasah, serta pesantren dan lain sebagainya.

Kaitannya kajian terdahulu diantaranya terdapat temuan bahwa manajemen pendidikan karakter gotong royong di Pesantren Ummul Quro AlIslami Leuwiliang Bogor tidak terlepas dari fungsi-fungsi manajemen pendidikan karakter. Sedangkan fungsi manajemen pendidikan karakter mencakup perencanaan, pengorganisasian, pelaksanaan, dan pengawasan. Karakter gotong royong tidak dirumuskan dalam perencanaan manajemen pendidikan karakter gotong royong, akan tetapi, dalam pelaksanaannya karakter gotong royong nampak pada komponen pesantren (Maulana, 2020). Sedangkan dalam penelitian lainnya diketahui bahwa manajemen pembelajaran Tahsin AI-Quran yang dilakukan mulai perencanaan, pelaksanaan dan penilaian sehingga pembelajaran Tahsin Al-Quran berjalan secara efektif dan efisien. Pengikatan kualitas pendidik, sarana dan prasarana pun terus dilakukan di SD Istiqamah Kota Bandung. Sehingga menghasilkan siswa yang lancar dalam bacaannya serta bisa melanjutkan ke tahap Tahfidz Al-Quran dan menyelesaikannya sebanyak 2 juz (Khoiruddin \& Kustiani, 2020).

Maka dari itu di era yang serba digital ini yaitu Era Revolusi Industri 4.0 perlu adanya revitaslisasi kajian mengenai prinsip-prinsip dalam Manajemen Pendidikan Islam guna mewujudkan manajemen yang kokoh dan unggul. Banyak muncul pertanyaan apa perbedaan Manajemen Pendidikan Islam dengan manajemen pendidikan lainnya. Contohnya dengan adanya manajemen pendidikan umum memang secara general sama. Artinya ada banyak atau bahkan mayoritas kaidah-kaidah manajerial yang dapat digunakan oleh seluruh manajemen, namun secara spesifikasi yang terdapat kekhususan-kekhususan yang sangat membutuhkan penanganan yang spesial pula. Inti dari pada manajemen dalam bidang apapun sama, hanya saja variabel yang dihadapinya 
berbeda tergantung pada bidang apa manajemen tersebut digunakan dan dikembangkan. Perbedaan variabel ini membawa perbedaan kultur yang kemudian memunculkan perbedaan (Ahmad Afan, 2015). Adapun tujuan dalam penelitian ini yaitu untuk mengetahui prinsip-prinsip dasar Manajemen Pendidikan Islam yang terkandung dalam Al-Quran dan relevansinya dengan kehidupan Era Revolusi Industri 4.0 sekarang ini.

\section{METODE}

Bagian pendekatan yang digunakan dalam penelitian ini adalah pendekatan kualitatif. Pendekatan kulalitatif adalah metode penelitian yang berlandaskan positivism (Sugiyono, 2017). Pendekatan ini dilakukan untuk mendapatkan data tentang kondisi sebenarnya di era kehidupan saat ini tentang eksistensi daripada prinsip-prinsip Manajemen Pendidikan Islam yang ada pada Al-Quran.

Jenis penelitian ini adalah penelitian kualitatif dalam penelitian kepustakaan (library research). Penelitian yang dilakukan dengan mengkaji berbagai data yang terkait dengannya, baik yang berasal dari sumber data utama (primary sources) maupun sumber data pendukung (secondary sources), sehingga dapat ditemukan ide atau gagasan entang konsep atau prinsip dari Manajemen Pendidikan Islam yang ada pada Al-Quran. Adapun yang menjadi sumber primer adalah Al-Quran sebagai sumber utama untuk mendapatkan pemikiran terkait Manajemen Pendidikan Islam penulis mengambil ayat-ayat yang berkaitan antara lain Surat Al-A'raf ayat 29, Surat Al-Ahzab ayat 24, Surat Al-Zumr ayat 33, Surat At-Taubah ayat 119, Surat Muhammad ayat 21, Surat AnNisa ayat 58, dan Surat Al-Maidah ayat 8 . Kemudian sumber skundernya adalah data diperoleh dari karya-karya penelitian baik skripsi, thesis, diserta, jurnal dan lain-lain yang menuangkan pemikirannya dalam batas relavansinya dengan persoalan yang diteliti.

Metode analisisnya menggunakan metode pendekatan kualitatif. Dengan demikian analisa terhadap data-data yang telah terkumpul dari sumber-sumber primer maupun skunder dengan penjelajahan studi kepustakaan, diklasifikasi sesuai dengan temanya, diseleksi dan kemudian disusun sesuai kategori data yang telah ditentukan.

\section{HASIL DAN PEMBAHASAN}

Prinsip dasar Manajemen Pendidikan Islam yang notabene mengandung berbagai prinsip umum yang fleksibel sehingga ia sejalan dengan kemajuan dan perkembangan yang baik pula, khususnya di Era Revolusi Industri 4.0 ini. Prinsipprinsip inilah yang membedakan antara manajemen pendidikan secara umum dengan Manjemen Pendidikan Islam. Mengenai prinsip-prinsip Manajemen Pendidikan Islam dalam Al-Quran, maka secara terperinci beberapa diantara prinsip dasar Manajemen Pendidikan Islam jika diterapkan dalam konteks persekolahan atau madrasah dan pesantren dapat diuraikan sebagai berikut.

\section{Prinsip Ikhlas}

Dalam mengelola madrasah, sekolah ataupun pesantren pada hakikatnya adalah sebuah kepercayaan dan tugas amanah dari Allah SWT. Sering kali dalam aplikasinya kita menghadapi beban tugas yang tidak sebanding dengan 
materi yang akan diperoleh. Jika kita berprinsip materialistis, maka tentu yang akan terjadi adalah kurang optimalnya pekerjaan yang dilakukan, hal ini disebabkan kita akan selalu membandingkan apa yang kita kerjakan dengan apa yang kita peroleh. Dalam kaitannya hal ini, keikhlasan adalah sebuah prinsip yang akan mendorong kita untuk berbuat yang terbaik meski apa yang kita peroleh tidak sebanding dengan antara materi duniawi yang didapatkan, ini dikarenakan kita yakin bahwa apa yang kita lakukan semata-mata sebagai wujud ibadah dan semata-mata mengharap ridha dari Allah SWT. Sebagaimana firman Allah SWT dalam Alquran Surat Al-A'raf ayat 29 yang berbunyi sebagai berikut

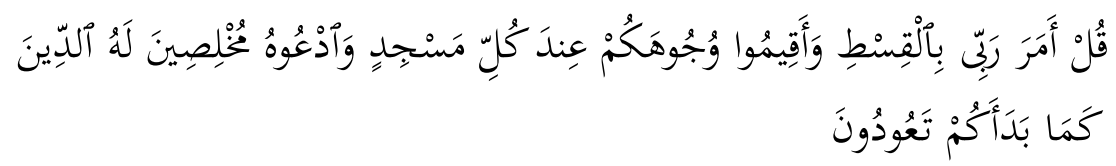

Artinya: Dan katakanlah luruskanlah muka (diri) mu setiap shalat dan sembahlah Allah SWT dengan mengikhlaskan ketaatanmu kepada-Nya. Sebagaimana Dia telah menciptakan kamu pada permulaan (demikian pulalah) kamu akan kembali kepada-Nya.

Ayat di atas mengajarkan agar manusia senentiasa mengikhlaskan diri dari segala bentuk peribadatan kita semata-mata karena Allah SWT, disertai dengan keyakinan bahwa Allah SWT pasti akan memberikan balasan yang setimpal atas apa yang ibadah kita lakukan itu. Konsekuensi logisnya jika sebuah sekolah atau pesantren dipimpin oleh seorang manajer yang memiliki prinsip ikhlas karena Allah SWT, maka niscaya sekolah atau pesantren itu akan mendapatkan perlakukan manajerial terbaik yang diharapkan mampu dilakukan oleh manajer tersebut, dan hal ini tentu akan sangat berdampak kepada kualitas sekolah atau pesantren tersebut ke depannya.

Dalam konteks kekinian terkait lembaga pendidikan Islam mulai dari sumber daya manusia yang merupakan tenaga atau personel kependidikan yang terdiri dari kepala sekolah, kemudian tenaga pendidik, dan pegawai tata usaha sampai dengan pesuruh atau bawahan (Hasbullah, 2006, p. 111). Itu semua personel pendidikan tersebut harus dikelola secara profesional dan matang dalam hal mendoktrin dalam hal ikhlas, luruskan niat dengan niat yang tulus, dan berniat hanya mengharapkan ridha ilahi Rabbi yang maha ikhlas sesuai dengan bidang dan keahliannya masing-masing. Manajemen dalam ranahnya membangkitkan cita rasa yang ikhlas ini, salah satu bidang ilmu pengetahuan yang telah berkembang dan diterapkan dalam berbagai tatanan organisasi, baik itu pemerintahan, perusahaan, sosial, maupun pendidikan formal maupun non formal. Dasar keihlasan inilah yang harus ditanamkan.

Adanya penerapan ilmu manajemen tersebut, diharapkan organisasi maupun lembaga dapat mencapai tujuan-tujuannya yang ingin dicapai melalui disiplin ilmu dalam prinsip ikhlas secara efektif dan efisien, serta menghasilkan produktivitas yang tinggi dengan prinsip ikhlas tersebut. Kendatipun ilmu manajemen itu berasal dari barat, dan telah berkembang ke seluruh dunia, akan tetapi sesungguhnya melalui Al-Quran dan Al-Hadits, Islam telah melahirkan sekaligus meletakkan dasar-dasar manajemen dalam diri seseorang maupun kelompok, dari mulai kehidupan pribadi atau personal, sosial sampai pada memanajemen kehidupan secara lebih luas dan terarah. Tetapi, karena umat 
Islam tidak lagi mau menggali kandungan Al-Quran sebagaimana pada zaman Islam klasik dahulu, maka pada saat ini baik ilmu pengetahuan maupun peradaban juga termasuk ahli-ahli manajemen lebih banyak lahir dari dunia barat.

Pendidikan Islam yang notabene merupakan sebuah proses transformasi yang di terapkan bagi setiap insan ini dalam ranah nilai-nilai Islam kepada peserta didik sebagai bekal untuk mencapai kebahagiaan dan kesejahteraan di dunia dan di akhirat. Dengan demikian pula, maka yang dinamakan sebuah Manajemen Pendidikan Islam itu merupakan proses pemanfaatan semua sumber daya yang dimiliki oleh umat Islam, lembaga pendidikan atau lainnya, baik itu perangkat keras maupun lunak. Pemanfaatan tersebut dilakukan guna menjadikan terobosan baru melalui kerjasama dengan orang lain secara efektif dan efisien serta produktif guna tercapainya sebuah kebahagiaan dan kesejahteraan baik di dunia maupun di akhirat (Ramayulis, 2008, p. 362).

Selain daripada itu semua diatas yang sudah dijelaskan, konsep Manajemen Pendidikan Islam perspektif atau pandangan AI-Quran sendiri yaitu diantaranya konsep fleksibel. Fleksibel ini tidaklah kaku dalam artian lentur. Berdasarkan hasil pengamatan walaupun sifatnya masih terbatas, hal ini menunjukkan bahwa sekolah atau madrasah meraih prestasi unggul. Hal ini justru dikarenakan adanya fleksibilitas pengelolanya dalam menjalankan tugastugasnya. Artinya jika dikaitkan dengan keikhlasan dalam menjalankan tugastugas dan tupoksi para SDM ini akan menimbulkan kelenturan dalam suatu manajemen. Lentur disini bermakna manajemen yang demkoratis (Suprayogo, 1994, p. 74).

\section{Prinsip Jujur}

Salah satu sifat yang dimiliki oleh baginda Rasulullah SAW yang dibawa sejak sebelum masa kenabian tiada lain adalah sifat jujur (Hidayat \& Wijaya, 2017, p. 10). Jujur ini menjadi identitas seorang Nabi dan Rasul Muhammad SAW yang menjadikannya dikenal dan dipercaya oleh seluruh masyarakat Arab pada kala itu. Tentu hal ini menjadi uswah bagi kita sebagai umatnya, betapa kejujuran kemudian akan menjadi modal untuk memimpin umat. Jika kita berkaca pada realita manajerial di Era Revolusi Industri 4.0 ini, maka kejujuran adalah sesuatu yang sangat mahal dan langka. Munculnya kasus KKN (korupsi, kolusi, dan nepotisme) yang semakin merambah di kalangan para pejabat contohnya, mulai dari pejabat tinggi negara, hingga kepada level pejabat di sekolah mengindikasikan betapa semakin memudarnya sifat kejujuran, hal ini dikarenakan bagaimanapun perilaku KKN itu terjadi ketika orang sudah mengabaikan kejujuran. Beberapa ayat Al-Quran berbicara tentang kejujuran, diantaranya dalam Surat Al-Ahzab ayat 24. Surat Al-Zumr ayat 33, Surat AtTaubah ayat 119 dan Surat Muhammad ayat 21 dengan penjelasan sebagai berikut.

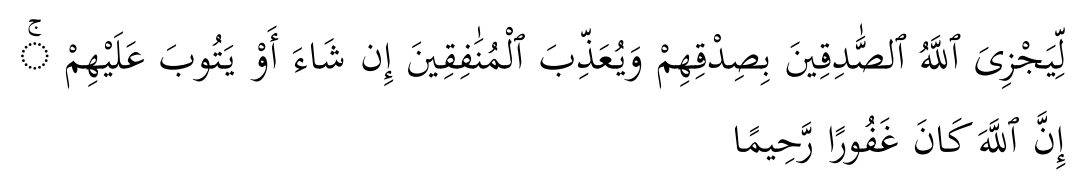

Artinya: Supaya Allah memberikan balasan kepada orang-orang yang benar itu karena kebenarannya, dan menyiksa orang munafik jika dikehendaki-Nya, atau 
menerima taubat mereka. Sesungguhnya Allah adalah Maha Pengampun lagi Maha Penyayang.

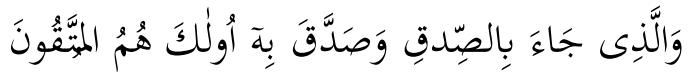

Artinya: Orang yang membawa kebenaran (Muhammad) dan yang membenarkannya, mereka itulah orang-orang yang bertaqwa. (QS. Al-Zumr: 33)

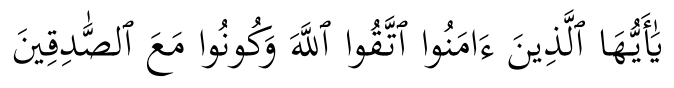

Artinya: Hai orang-orang yang beriman, bertaqwalah kepada dan hendaklah kamu bersama orang-orang yang jujur (QS. At-Taubah: 119).

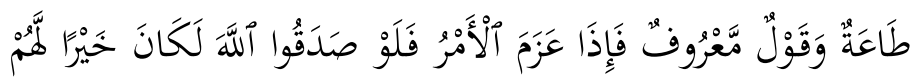

Artinya: Jikalau mereka jujur kepada Alloh, niscaya yang demikian itu lebih baik bagi mereka (QS: Muhammad: 21)

Dalam konteks persekolahan atau pesantren misalnya, kejujuran menjadi prinsip yang sangat penting dimiliki oleh pimpinan madrasah/sekolah/pesantren. Seorang pimpinan madrasah/sekolah/pesantren memiliki legitimasi untuk menetapkan banyak kebijakan sekolah, termasuk kebijakan dalam anggaran. Dalam konteks ini, peluang untuk merekayasa data dan melakukan kecurangan sangat terbuka lebar. Namun jika memiliki prinsip kejujuran, maka tentunya sebesar apapun peluang untuk melakukan perilaku kebohongan, tentu tidaklah akan dilakukan. Konsekuensi bagi sekolah yang dipimpin oleh seorang manajer yang jujur tentu sekolah itu akan mendapatkan hak sesuai dengan peruntukan yang diberikan kepadanya. Program-program pemerintah yang saat ini banyak berpihak kepada pengembangan kualitas sekolah tentu akan tepat sasaran dan peningkatan kualitas pendidikan yang diharapkan akan menjadi sebuah keniscayaan dan tidak akan banyak mengalami kebocoran dana atau penyalahgunaan wewenang.

Amanah dalam agama Islam menjelaskan bahwa jabatan merupakan sebuah amanah yang harus dipertanggungjawabkan. Pertanggungjawaban ini tidak hanya di dunia saja kepada manusia, tetapi juga di akhirat kelak kepada Allah SWT. Amanah dimaknai sebagai kepercayaan, maka seseorang yang diberi amanah ialah orang yang mendapatkan kepercayaan untuk memegang suatu tugas tertentu. Allah SWT berfirman dalam AI-Quran Surat An-Nisa ayat 58 sebagai berikut.

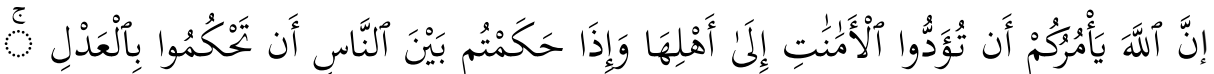

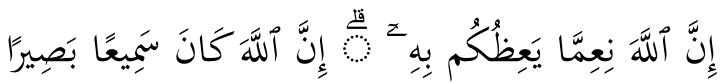

Artinya: Sesungguhnya Allah menyuruh kamu menyampaikan amanat kepada yang berhak menerimanya, dan (menyuruh kamu) apabila menetapkan hukum di antara manusia supaya kamu menetapkan dengan adil. Sesungguhnya Allah 
memberi pengajaran yang sebaik-baiknya kepadamu. Sesungguhnya Allah adalah Maha Mendengar lagi Maha Melihat.

Berdasarkan penjelasan ayat di atas, maka amanah baiknya hendak diberikan kepada orang yang berhak menerimanya, diantaranya yang berhak adalah orang-orang yang memenuhi kriteria sesuai dengan karakteristik pekerjaan atau tugas yang akan diembannya tersebut. Selanjutnya, orang yang diberi amanah harus mewujudkan amanah yang diembannya tersebut dan tidak melakukan penyelewengan atau penyalahgunaan. Dalam konteks persekolahan maupun pesantren, jabatan pimpinan sekolah dan pengasuh pondok pesantren adalah sebuah amanah. Seorang pemimpin sekolah atau guru atau dosen yang memiliki prinsip bahwa pekerjaan atau tugasnya itu adalah sebuah amanah, maka dia tentu akan selalu berusaha melaksanakan kepercayaan tersebut sesuai dengan apa yang ditugaskan dan yang menjadi kewenangan yang diberikan kepadanya. Penyelewengan atau penyalahgunan terhadap suatu tugas dan wewenang tertentu yang diembankan kepadanya adalah mengindikasikan bahwa orang tersebut adalah orang yang tidak amanah. Maka, sekolah atau pesantren yang dihuni oleh orang-orang yang amanah dengan sendirinya akan mendapatkan sebuah kultur kehidupan dimana semua orang berpegang dan bekerja sesuai dengan apa yang menjadi tugas dan kewenangannya, dan hal ini tentu akan sangat berdampak signifikan terhadap kualitas sekolah atau pesantren tersebut. Segala jenis program yang dibuat sekolah atau pesantren tentu akan relatif lebih mudah untuk segera diwujudkan.

\section{Prinsip Adil}

Salah satu prinsip dasar yang tidak kalah penting dalam Manajemen Pendidikan Islam adalah sifat adil. Menurut Abuddinnata tentang keadilan adalah sebuah istilah yang digunakan untuk menunjukkan pada persamaan atau bersikap tengah-tengah (tawasuth) diantara dua perkara (Abudinata, 2003, p. 144). Keadilan dalam hal ini, yang terjadi berdasarkan keputusan akal yang dikonsultasikan dengan agama. Adil sering juga dimaknai sebagai suatu sikap yang moderat, obyektif terhadap orang lain dalam memberikan hukuman atau punishment yang sering diartikan pula dengan persamaan dan keseimbangan dalam memberikan hak orang lain tanpa ada yang dilebihkan atau dikurangi. Berlaku adil sangatlah dianjurkan dalam kehidupan sehari-hari, bahkan menjadi salah satu indikator ketaqwaan seseorang sebagaimana Firman Allah SWT dalam Al-Quran Surah Al-Maidah ayat 8 berikut ini.

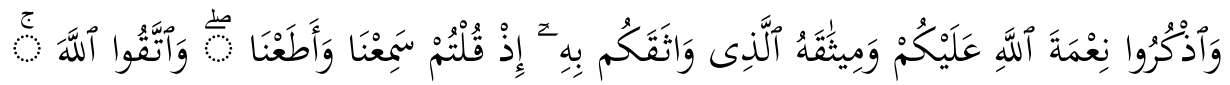

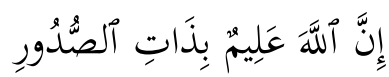

Artinya: Dan ingatlah karunia Allah kepadamu dan perjanjian-Nya yang telah diikat-Nya dengan kamu, ketika kamu mengatakan: "Kami dengar dan kami taati". Dan bertakwalah kepada Allah, sesungguhnya Allah Mengetahui isi hati (mu). 


$$
\text { وَألسَسَمَاءَ رَفَفَعَا وَوَضَعَ الْمِيزَانَ }
$$

Artinya: Dan Allah telah meninggikan langit dan Dia meletakkan neraca (keadilan).

Dalam konteks persekolahan atau pesantren, keadilan sering kali menjadi hal yang sangat sensitif dan sangat rentan timbulnya konflik ketika sifat adil itu tidak diwujudkan. Pemberian gaji atau tunjangan misalnya bagi guru atau dosen sampai pemberian tugas atau wewenang dan tanggung jawab adalah diantara bagian manajemen persekolahan atau madrasah yang memiliki peluang melahirkan ketidakadilan. Oleh karenanya, manajemen dalam pendidikan Islam, keadilan harus didahulukan guna menjadi prinsip dasar yang dimiliki oleh seorang pemimpin di dalamnya. Sebuah sekolah atau madrasah yang memiliki pemimpin yang adil di dalamnya, akan memiliki kultur sekolah atau madrasah yang kondusif bagi pengembangan kualitas didalamnya.

Pendidikan Islam juga dituntut ideal. Maksudnya pendidikan harus memunculkan bagaimana sifat yang transenden dan integral, hal ini sangat berguna sekali dalam hal ini yang berkaitan antara alam fisik dan metafisik, karena keduanya saling berhubungan satu sama lain. Pendidikan juga dituntut harus mampu melatih perasaan peserta didik sehingga dalam hal sikap hidup, tindakan, keputusan dan pendekatan terhadap segala jenis pengetahuan, hal tersebut dipengaruhi sekali oleh nilai spiritual (Abduloh \& Ahyani, 2020)

Untuk meminimalisir hal di atas, yakni mengenai salah satu prinsip dasar yang tidak kalah penting dalam Manajemen Pendidikan Islam adalah sifat adil di sekolah peserta didik harus ditanamkan nilai-nilai pendidikan Islam. Pendidikan Islam merupakan usaha orang dewasa muslim yang bertakwa secara sadar mengarahkan dan membimbing pertumbuhan serta perkembangan fitrah (kemampuan dasar) anak didik melalui ajaran Islam ke arah titik maksimal pertumbuhan dan perkembangannya. Dengan hadirnya pendidikan Islam maka peserta didik mengerti hal yang baik dan buruk dan dengan itu secara tidak langsung tau akan arti kebersamaan, toleran, dan mampu menyesuaikan diri dalam berbagai perbedaan dan kemajemukan (Permana \& Ahyani, 2020). Dalam pendidikan multikultural ini diharapkan sifat adil dalam Manajemen Pendidikan Islam sebagai dasar atau pondasi yang tergabung dalam Manajemen Pendidikan Islam ini dapat dimanfaatkan teori keadilan ini.

\section{SIMPULAN}

Dari pemaparan diatas mengenai permasalahan prinsip-prinsip dasar dalam Menejemen Pendidikan Islam yang terkandung dalam AI-Quran dan relevansinya terhadap kehidupan di Era Revolusi Industri 4.0 adalah pinsip ikhlas, jujur, amanah dan adil. Hal ini secara rinci disinggung dalam Al-Qur'an diantaranya dalam Surat Al-A'raf ayat 29 yang mengandung sifat Ikhlas. Kemudian dalam Surat Al-Ahzab ayat 24, Surat Al-Zumr ayat 33, Surat AtTaubah ayat 119, Surat Muhammad ayat 21, dan Surat An-Nisa ayat 58 yang mengandung pembahasan tentang sifat Jujur. Serta dalam Surat Al-Maidah ayat 8 mengandung tentang prinsip adil. Untuk meminimalisir hal di atas, yakni mengenai salah satu prinsip dasar yang tidak kalah penting dalam Manajemen Pendidikan Islam adalah sifat adil di sekolah, peserta didik harus ditanamkan nilai-nilai pendidikan Islam yakni pendidikan Islam multikultural sebagai dasar 
atau pondasi yang tergabung dalam Manajemen Pendidikan Islam ini dapat dimanfaatkan teori keadilan.

\section{REFERENSI}

Abduloh, A. Y., \& Ahyani, H. (2020). Pendidikan Hati Menurut Al-Ghazali (Keajaiban Hati: Penjelasan Tentang Perbedaan Antara Dua Maqom). Tawadhu, 4(2), 1209-1227. https://ejournal.iaiig.ac.id/index.php/TWD/article/view/289

Abudinata, A. (2003). Akhlak Tasawuf. PT Raja Grafindo Persada.

Ahmad Afan, Z. (2015). Urgensi Manajemen Pendidikan Islam. Ummul Quro, 5(1), 24-37. http://ejournal.kopertais4.or.id/index.php/qura/issue/view/531

Departemen Pendidikan Nasional, D. P. N. (2013). Kamus Besar Bahasa Indonesia. Balai Pustaka.

Echols, J. M., \& Hassan, S. (2006). Kamus Inggris Indonesia. PT Gramedia Pustaka Utama.

Engkoswara, E., \& Komariah, A. (2012). Administrasi Pendidikan. Alfabeta.

Hasbullah, H. (2006). Otonimi Pendidikan (Kebijakan Otonomi Daerah dan Implikasinya terhadap Penyelenggaraan Pendidikan). PT Raja Grafindo Persada.

Hidayat, R., \& Wijaya, C. (2017). Ayat-Ayat Al-Quran Tentang Manajemen Pendidikan Islam. Lembaga Peduli Pengembangan Pendidikan Indonesia.

Khoiruddin, H., \& Kustiani, A. W. (2020). Manajemen Pembelajaran Tahsin AlQuran Berbasis Metode Tilawati. Jurnal Isema: Islamic Educational Management, 5(1), 55-68. https://doi.org/10.15575/isema.v5i1.5546

Langgulung, H. (2000). Asas-Asas Pendidikan Islam. Al-Husna Zikra.

Maulana, I. (2020). Manajemen Pendidikan Karakter Gotong Royong .Jurnal Isema: Islamic Educational Management, 5(1), 127-138. https://doi.org/10.15575/isema.v5i1.5393

Munawwir, A. M. (1997). Kamus Al-Munawwir Arab-Indonesia Terlengkap. Pustaka Progresif.

Permana, D., \& Ahyani, H. (2020). Implementasi Pendidikan Islam Dan Pendidikan Multikultural Pada Peserta Didik. Tawadhu, 4(1), 995-1006. https://ejournal.iaiig.ac.id/index.php/TWD/article/view/219

Ramayulis, R. (2008). IImu Pendidikan Islam. Kalam Mulia.

Sugiyono. (2017). Metode Penelitian Kuantitatif, Kualitatif dan R\&D. Alfabeta.

Suprayogo, I. (1994). Revormulasi Visi Pendidikan Islam. STAIN Press. 